\begin{tabular}{c} 
DARMABAKTI CENDEKIA: \\
Journal of Community Service and Engagements \\
www.e-journal.unair.ac.id/index.php/DC \\
\hline
\end{tabular}

\section{UTILIZATION OF AGRICULTURAL PRODUCTS FOR THE MANAGEMENT AND PREVENTION STUNTING THROUGH EMPOWERING HEALTH CADRES IN JEMBER DISTRICT}

\author{
PEMANFATAAN HASIL PERTANIAN UNTUK \\ PENATALAKSANAAN DAN PENCEGAHAN STUNTING MELALUI \\ PEMBERDAYAAN IBU KADER KESEHATAN DI KABUPATEN \\ JEMBER
}

Scope:

Health

\author{
Anisah Ardiana ${ }^{1}$, Alfid Tri Afandi ${ }^{*}$, Ardiyan Dwi Masaid ${ }^{2}$, Ninna Rohmawati ${ }^{3}$ \\ ${ }^{1}$ Department of Nursing Sciences, Faculty of Nursing, University of Jember, Jember-Indonesia \\ ${ }^{2}$ Department of Agricultural Product Technology, Faculty of Agricultural Technology, University of Jember, Jember-Indonesia \\ ${ }^{3}$ Department of Nutrition, Faculty of Public Health, University of Jember, Jember-Indonesia
}

\section{A B S T R A C T}

Background: Stunting is a problem that cannot be considered ordinary. Short toddlers (stunting) can occur due to poor nutrition and nutritional intake and lack of knowledge about stunting. Purpose: Transferring knowledge about how to prevent and manage stunting or short toddlers. Method: counseling and empowering health cadres by using tools such as LCD projectors and using leaflets and interactive discussions. Results: The implementation of this activity included advice and health cadre assistance in conducting health education to the community. Counseling for health cadres was done first to increase cadre knowledge. After that, support was given to health cadres to lead health education to the community around the village. Conclusion: After conducting mentoring activities on health cadres, which was a village program under the guidance of the University of Jember, it could increase the knowledge and motivation of cadres in conducting health education in the context of preventing and managing stunting infants.

\section{A B S T R A K}

Latar Belakang: Kejadian Stunting merupakan suatu permasalahan yang tidak dapat dianggap biasa. Balita pendek (stunting) dapat terjadi dikarenakan asupan nutrisi dan gizi kurang baik serta kurangnya pengetahuan tentang stunting. Tujuan: Mentransfer ilmu tentang bagaimana melakukan pencegahan dan penatalaksanaan terhadap kejadian stunting atau balita pendek. Metode: melakukan penyuluhan dan pemberdayaan pada kader kesehatan dengan menggunakan bantuan alat seperti LCD proyektor dan menggunakan leaflet serta diskusi interaktif. Hasil: Pelaksanaan dalam kegiatan ini meliputi kegiatan penyuluhan dan pendampingan kader kesehatan dalam melaksanaakan Pendidikan kesehatan kepada masyarakat. Penyuluhan kepada kader kesehatan dilakukan terlebih dahulu untuk meningkatkan pengetahuan kader. Setelah itu dilakukan pendampingan kepada kader kesehatan untuk melakukan Pendidikan kesehatan kepada masyarakat sekitar desa. Kesimpulan: Setelah melakukan kegiatan pendampingan pada kader kesehatan yang merupakan program desa binaan universitas jember dapat meningkatkan pengetahuan dan motivasi kader dalam melakukan Pendidikan kesehatan dalam rangka pencegahan dan penatalaksanaan terhadap balita stunting.

\author{
AR T I CLE INFO \\ Recieved 31 Oktober 2019 \\ Accepted 17 Juni 2020 \\ Online 28 Juni 2020 \\ *Correspondence (Korespondensi): \\ Alfid Tri Afandi \\ E-mail: \\ alfid@unej.ac.id
}

Keywords:

Stunting; Health Cadre;

Nutrition

Kata kunci:

Stunting; Kader Kesehatan; Nutrisi 


\section{PENDAHULUAN}

Kecamatan Kalisat Kabupaten Jember merupakan salah satu kecamatan di wilayah Kabupaten Jember yang memiliki wilayah pertanian yang cukup luas. Berdasarkan data Badan Pusat Statistik Kabupaten Jember (2017), diketahui bahwa persentase wilayah tanah persawahan di kecamatan Kalisat sebesar 57,09\%; tegalan 18,88\%; bangunan dan halaman $16,90 \%$; lainnya $7,13 \%$. Hal ini menunjukkan bahwa tiga perempat wilayah tanah di kecamatan Kalisat dapat dimanfaatkan untuk menghasilkan berbagai hasil pertanian.

Secara administratif, Kecamatan Kalisat memiliki 12 Desa yang berada di wilayah seluas $50,53 \mathrm{~km}^{2}$. Desa Sumberkalong merupakan salah satu desa di wilayah kecamatan Kalisat dengan jumlah penduduk sebesar 3.718 jiwa pada tahun 2016 yang tersebar di 5 Dusun. Desa Sumberkalong memiliki 20 kader kesehatan posyandu yang cukup aktif. Berdasarkan hasil wawancara dengan ibu Sekretaris Desa (Ibu Sekdes) diperoleh informasi bahwa di setiap dusun telah ada beberapa kader kesehatan posyandu yang aktif melaksanakan program posyandu di wilayah dusunnya masingmasing. Ibu Sekdes berperan sebagai koordinator kader di Desa Sumberkalong. Menurut pengakuan Ibu Sekdes, ibu-ibu kader kesehatan di Desa Sumberkalong memiliki motivasi yang sangat tinggi dalam penatalaksanaan dan pencegahan balita stunting di wilayah Desa Sumberkalong Kecamatan Kalisat. Ibu Sekdes selaku koordinator kader kesehatan posyandu juga tampak antusias dan memberikan respon positif terhadap upaya mengatasi dan mencegah balita stunting di Desa Sumberkalong.

Seperti diketahui bersama, stunting merupakan kondisi gagal tumbuh pada tubuh dan otak yang diakibatkan keadaan kurang gizi dalam waktu yang lama. Sehingga, anak stunted memiliki tubuhyanglebih pendek darianaknormal seusianya dan memiliki keterlambatan berpikir (Yunita, 2018). Hal ini dapat mempengaruhi kemampuan dan prestasi anak di sekolah, produktivitas dan kreativitas anak pada usia produktif (Kementerian Kesehatan RI, 2018). Menteri Kesehatan RI, Nila Farid Moeloek (2018) menyatakan bahwa peran semua sektor dan tatanan masyarakat dibutuhkan untuk mengatasi masalah kesehatan, termasuk melalui peningkatan pemberdayaan perempuan, seperti pemberdayaan ibu kader kesehatan. Antusiasme dan tingginya motivasi ibu-ibu kader kesehatan Desa Sumberkalong dapat menjadi potensi sumber daya manusia yang efektif untuk penatalaksanaan dan pencegahan stunting di Desa Sumberkalong Kecamatan Kalisat. Hal ini dapat menjadi faktor pendukung pelaksanaan program Pengembangan Desa Binaan.

Desa Sumberkalong juga memiliki potensi pertanian yang cukup baik. Luas wilayah desa Sumberkalong adalah $4.010 \mathrm{~km}^{2}$ atau $401 \mathrm{Ha}$. Beberapa hasil pertanian masyarakat Desa Sumberkalong antara lain padi, jadung, kedele, kacang tanah dan sayuran. Data Badan Pusat Statistik Kabupaten Jember (2017) menyebutkan bahwa luas tanam kedele di desa Sumberkalong adalah $3 \mathrm{Ha}$, dengan hasil produksi mencapai 5 ton. Sedangkan hasil pertanian berupa Kacang memiliki luas tanam $1 \mathrm{Ha}$, dengan hasil produksi sebanyak 2 ton. Pada tahun 2016, Desa Sumberkalong mampu memproduksi 2.888 ton padi, dengan luas tanam padi $610 \mathrm{Ha}$. Desa sumberkalong juga mampu memproduksi 1.146 ton jagung dari 174 Ha luas tanam. Dari data tersebut dapat disimpulkan bahwa Desa Sumberkalong memiliki potensi pertanian yang dapat dimanfaatkan dalam penatalaksanaan dan pencegahan balita stunting.

Ketersediaan bahan makanan dapat membantu pemenuhan gizi seimbang, sehingga peran perawat dalam pencegahan masalah stunting bisa dimulai dengan preventif dan promotif terkait bahan makanan (American Board for Occupational Health Nurse, 2014). Masalah stunting salah satunya dipengaruhi oleh rendahnya akses terhadap makanan, baik dari jumlah maupun kualitas gizi. Kementerian Kesehatan Republik Indonesia (2018) telah memperkenalkan istilah "isi piringku" yang artinya dalam satu porsi makanan, setengah piring diisi oleh sayur dan buah, setengahnya lagi diisi dengan sumber protein (nabati maupun hewani) dengan proposi yang lebih banyak daripada karbohidrat. Selain itu, berdasarkan hasil penelitian Ardiana dan Purwandari (2011) tentang pengaruh pemberian tahu-tempe terhadap peningkatan berat badan pada balita gizi buruk di Kecamatan Kalisat pada tahun 2018, diperoleh hasil bahwa pada kelompok eksperimen terjadi peningkatan berat badan ratarata sebesar 0,4438 kg setelah dilakukan perlakuan pemberian tahu-tempe. Pada kelompok kontrol terjadi perubahan berat badan rata-rata 0,1250 kg. Pemberian tahu-tempe dilaksanakan dalam waktu 1 bulan. Penelitian tersebut menyimpulkan bahwa terdapat pengaruh pemberian tahu-tempe terhadap peningkatan berat badan pada penderita gizi buruk.

Dengan demikian, melalui pemberdayaan ibuibu kader kesehatan yang memiliki motivasi yang tinggi dan ditunjang dengan hasil pertanian yang ada di Desa Sumberkalong dapat menjadi potensi daerah yang menunjang dalam penatalaksanan dan pencegahan stunting di Desa Sumberkalong. Melalui Program Pengembangan Desa Binaan ini, diharapkan ibu-ibu kader kesehatan 
Desa Sumberkalong dapat secara mandiri memanfaatkan hasil pertanian untuk program penatalaksanan dan pencegahan balita stunting.

\section{Pemasalahan Mitra}

Desa Sumberkalong merupakan salah satu desa di Kecamatan Kalisat yang saat ini masih ditemukan kasus balita stunting. Berdasarkan hasil wawancara dengan ibu Sekdes, didapatkan data bahwa terdapat 5 balita stunting di Desa Sumberkalong. Informasi yang didapatkan ibu Sekdes dari bidan Desa Sumberkalong, diketahui bahwa program posyandu telah dilaksanakan dan berjalan normal. Pendidikan kesehatan juga telah diberikan kepada ibu-ibu yang memiliki balita namun mereka masih kurang memahami kebutuhan nutrisi balita. Selain itu, bidan desa juga menyatakan faktor ekonomi juga menjadi salah satu penyebab tidak terpenuhinya kebutuhan gizi balita. Berdasarkan data BPS Kabupaten Jember (2017) terdapat 986 rumah tangga miskin di Desa Sumberkalong. Dengan demikian, dapat disimpulkan bahwa faktor tingkat pengetahuan dan tingkat ekonomi menjadi permasalahan utama yang dapat menyebabkan terjadinya stunting pada balita di Desa Sumberkalong. Hasil Riset Kesehatan Dasar oleh Kementerian Kesehatan RI (2010) memaparkan hasil bahwa masih sedikit pencapaian dari peningkatan penelitian di bidang pangan untuk meningkatkan status gizi.

Sarana kesehatan yang tersedia di Desa Sumberkalong cukup terbatas. DesaSumberkalong hanya memiliki 1 puskesmas pembantu dan 1 bidan desa. Masyarakat desa Sumberkalong yang ingin mendapatkan layanan kesehatan yang lebih komprehensif dapat menggunakan fasilitas RSD Kalisat yang berjarak cukup jauh sekitar 7 $\mathrm{km}$ dari Desa Sumberkalong. Dengan kurangnya fasilitas kesehatan di Desa Sumberkalong juga dapat menjadi salah satu penyebab ibu-ibu kurang berminat untuk memeriksakan kesehatan dan kebutuhan gizi anaknya. Tingkat kesadaran yang masih rendah dan faktor biaya terkait transportasi yang dibutuhkan untuk pergi ke fasilitas kesehatan juga menjadi permasalahan yang perlu dipertimbangkan. Melalui program Pengembangan Desa Binaan yang berfokus pada pemberdayaan ibu-ibu kader kesehatan yang sangat antusias dan aktif dalam kegiatan posyandu, maka program ini diharapkan dapat membantu ibu-ibu kader untuk secara mandiri mengatasi dan mencegah terjadinya balita stunting dengan memanfaat hasil pertanian Desa Sumberkalong.

Berdasarkan data BPS Kabupaten Jember (2017) diketahui bahwa jumlah bayi di Desa Sumberkalong adalah 51 bayi, jumlah Pasangan Usia Subur sebanyak 771 dan jumlah ibu hamil sebanyak 59 orang. Angka-angka ini perlu menjadi perhatian petugas kesehatan dan ibuibu kader kesehatan. Hal ini dapat menjadi faktor resiko terjadinya stunting jika tidak diberikan perhatian sejak dini. Stunting dapat terjadi akibat kekurangan gizi dalam waktu yang lama sejak janin masih dalam kandungan. Kementerian Kesehatan RI (2018) menyebutkan bahwa stunting dapat dicegah sejak masa kehamilan. Para calon ibu seharusnya memahami pentingnya memenuhi kebutuhan gizi saat hamil bagi janin yang dikandunganya. Beberapa hal yang hendaknya disosialisasikan kepada para calon ibu antara lain pentingnya melakukan inisiasi menyusui dini (IMD), pentingnya colostrum air susu ibu (ASI) bagi bayi baru lahir. Selain itu pemberian ASI eksklusif dapat diberikan sampai bayi berusia 6 bulan, serta ASI dapat dilanjutkan sampai usia 2 tahun, namun makanan pendamping ASI hendaknya sudah mulai diberikan. Para ibu juga hendaknya memantau tumbuh kembang anaknya dengan membawa anak ke Posyandu setiap bulan (Aridiyah dkk, 2014). Dengan demikian, terjadinya balita stunting dapat dicegah dan angka balita stunting dapat diturunkan sehingga tidak muncul kembali balita stunting.

Berdasarkan pemaparan di atas, maka permasalahan yang dihadapi oleh mitra dapat diuraikan sebagai berikut:

1. Kurangnya pemanfaatan hasil pertanian untuk penatalaksanaan dan pencegahan stunting.

2. Faktor ekonomi masyarakat yang mempengaruhi kemampuan masyarakat untuk membeli bahan makanan untuk memenuhi gizi yang seimbang.

3. Kurangnya pengetahuan dan kurangnya kesadaran masyarakat bahwa stunting dapat dicegah sejak masa kehamilan.

4. Kurang optimalnya penyebarluasan informasi tentang penatalaksanaan dan pencegahan stunting sejak dini melalui kegiatan non kesehatan atau kegiatan kemasyarakatan dan keagamaan seperti pengajian, PKK, arisan dan lain-lain.

\section{Solusi Yang Ditawarkan}

Berkaitan dengan permasalahan yang dialami, tim pelaksanaan pengabdian kepada masyarakat memberikan beberapa solusi. Solusi yang diberikan berupa penyuluhan dan pemberdayaan kader kesehatan serta adanya monitoring dan evaluasi terhadap proses pemberian pendidikan kesehatan. Kegiatan penyuluhan dan pendampingan diberikan oleh tim pengabdian yang berkompeten dalam bidangnya masing-masing yang sesuai dengan permasalahan pada mitra. Solusi yang diberikan diharapkan memberikan hasil sebagai berikut:

1. Kader kesehatan desa memiliki pemahaman 
dan pengetahuan yang cukup tentang stunting

2. Kader kesehatan desa diharapkan mengenali dan paham terkait pencegahan stunting

3. Diharapkan tidak terjadi kejadian stunting dengan meningkatnya pengetahuan kader dan ibu balita di desa.

\section{METODE PELAKSANAAN}

\section{Sasaran Pengabdian}

Dalam pelaksanaan kegiatan pengabdian kepada masyarakat ini, sasaran kegiatan adalah kader kesehatan yang sudah ada di desa dan ibuibu balita. Kegiatan dilakukan dengan beberapa tahap yaitu tahap penyuluhan pada kader dan pendampingan kader ketika melakukan penyuluhan kepada ibu balita. Penyuluhan dilakukan oleh tim kepada kader kesehatan yang terbentuk dengan topik stunting, pencegahan stunting dan penatalaksanaan stunting. Penyuluhan dilakukan dengan memberikan materi dan laflet, serta dilanjutkan dengan diskusi interaktif dengan kader, harapannya dapat meningkatkan pengetahuan kader kesehatan. Pendampingan dan monitoring dilakukan kepada kader kesehatan setelah mendapatkan semua topik yang diberikan pada waktu penyuluhan di awal. Pada kegiatan pendampingan, tim mendampingi kader dalam pemberian penyuluhan kesehatan kepada masyarakat dengan topik stunting. Berikut ini metode pendekatan yang digunakan untuk menyelesaikan masalah dan prosedur kerjanya:

a. Diskusi

Diskusi akan dilaksanakan untuk memaparkan permasalahan yang dihadapi oleh mitra dan menyamakan persepsi mengenai permasalahan dan solusi untuk mengatasi permasalahan tersebut. Diskusi akan diikuti oleh tim pengusul, ibu-ibu kader kesehatan dan perangkat desa. Melalui metode diskusi diharapkan bisa mendapatkan suatu kesepakatan dan keputusan bersama tentang sebuah masalah yang dibahas.
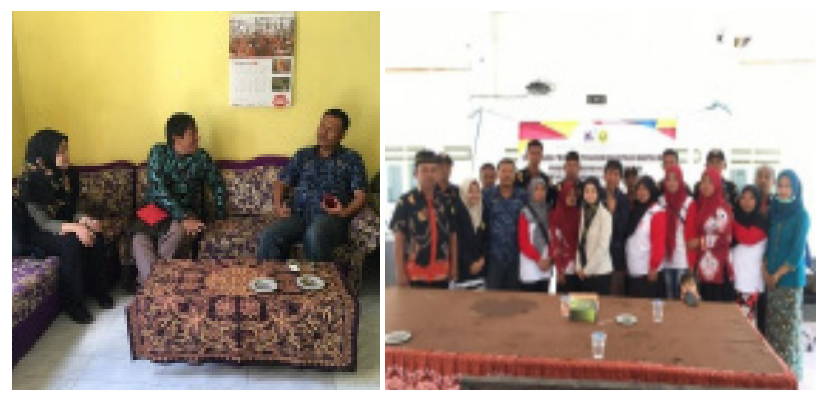

Gambar 1. Diskusi dengan Kades (kiri) dan perangkat desa (kanan) b. Penyuluhan

Penyuluhan tentang pemanfaatan hasil pertanian untuk pemenuhan kebutuhan gizi akan diberikan kepada ibu hamil, pasangan usia subur dan ibu-ibu yang memiliki balita. Penyuluhan tentang pentingnya pencegahan stunting sejak dini di masa kehamilan diberikan kepada masyarakat melalui kegiatan pengajian, PKK, arisan dan kegiatan lain yang memungkinkan warga berkumpul. Metode penyuluhan ini bermanfaat untuk menyebarkan informasi secara luas.

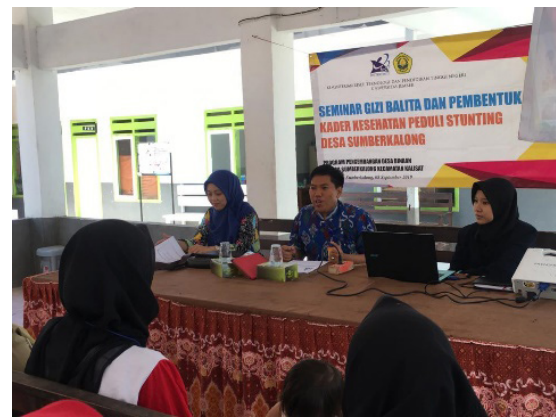

Gambar 3. Penyuluhan Kader

c. Pelatihan

Pelatihan yang akan diberikan meliputi pelatihan metode menanam dan memanen kedelai, pelatihan pengolahan kedelai menjadi susu kedelai dan pelatihan pemasaran. Pelatihan tersebut diharapkan dapat meningkatkan kemandirian ibu-ibu kader kesehatan.

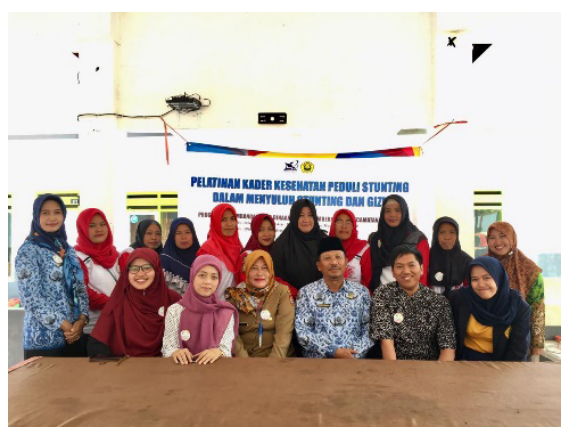

Gambar 4. Pelatihan Ibu Kader

d. Pembentukan kelompok dan pemberdayaan Pembentukan kelompok ibu kader kesehatan peduli stunting dan pemberdayaan ibu kader kesehatan dalam upaya penatalaksanaan dan pencegahan stunting. Pembentukan kelompok ibu kader kesehatan peduli stunting ditujukan untuk meningkatkan komitmen kader kesehatan untuk melaksanakan program penatalaksanaan dan pencegahan stunting secara komprehensif. Sehingga pemberdayaan perempuan dan masyarakat dapat secara efektif mengatasi permasalahan yang dihadapi. 


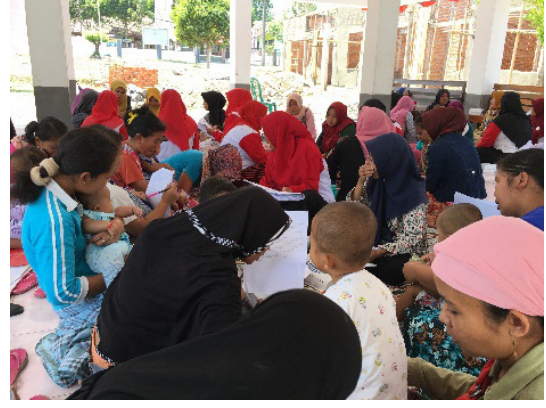

Gambar 5. Pendampingan Kader

\section{HASIL DAN PEMBAHASAN}

\section{Situasi Awal}

Kegiatan pengabdian dilakukan beberapa tahap. Pada tahap awal dilakukan pengukuran tingkat pengetahuan kader terkait stunting. Hasil dari pengukuran pengetahuan kader kesehatan menggunakan kuesioner pengetahuan terhadap stunting yang terdiri dari 15 soal dari penelitian Aridiyah dkk (2014) didapatkan dari sembilan kader kesehatan, hanya satu kader yang mendapatkan nilai maksimal. Pada tahap selanjutnya dilakukan pendidikan kesehatan terhadap kader kesehatan, sehingga dapat mengoptimalkan hasil yang ingin dicapai. Parameter keberhasilan kader kesehatan dapat dilihat dari meningkatnya pengetahuan kader, dengan mengisi form evaluasi yang sama seperti di awal. Hasil pengukuran didapatkan terdapat tujuh kader yang mendapatkan nilai maksimal dan dua kader salah pada 2 item pertanyaan. Dari hasil tersebut terdapat peningkatan pengetahuan pada kader kesehatan.

\section{Pelaksanaan Kegiatan}

Pada pelaksanaan kegiatan meliputi beberapa tahap yang sesuai dengan metode penyampaian dalam pengabdian masyarakat. Diawali dengan sosialisasi program, dilajutkan dengan pembentukan kader sampai dengan penyuluhan dan pendampingan kader ketika melakukan penyuluhan. Pada waktu melakukan pendampingan, kader diberi bekal sekaligus buku pegangan yang berisi materi tentang stunting beserta cara mengatasi dan mencegahnya, sehingga ketika kader kesehatan melakukan penyuluhan dapat menggunakan buku tersebut sebagai pedomannya. Sebelum pelaksanaan kegiatan penyuluhan kesehatan ibu balita diberikan kuesioner untuk diukur terlebih dahulu tingkat pengetahuannya. Dari 24 ibu balita yang mengikuti penyuluhan mendapatkan hasil rata-rata dengan nilai 63,61 dari 15 soal yang diberikan. Setelah itu dilakukan penyuluhan serta ibu balita dibentuk kelompok kecil (peer group support) untuk berdiskusi tentang materi yang sudah diberikan. Metode pendekatan peer group support digunakan karena dapat meningkatkan pengetahuan dari peserta yang mengikuti kegiatan diskusi dari awal sampai teakhir. Pada artikel Afandi (2016), peer group support juga dapat meningkatkan pengetahuan dari teman sebaya yang mengalami pengalaman yang sama, dalam pengabdian ini pengalaman dalam mengasuh balita merupakan hal yang sama diantara ibu balita. Setelah itu, kegiatan terakhir adalah evaluasi dengan pengukuran pengetahuan ibu balita dengan hasil nilai rata-rata 83,05 dari 15 soal. Hasil setelah dilakukan pengukuran sebelum dan setelah dilakukan penyuluhan dan diskusi kelompok dengan pendekatan peer group support didapatkan hasil adanya peningkatan pengetahuan ibu balita.

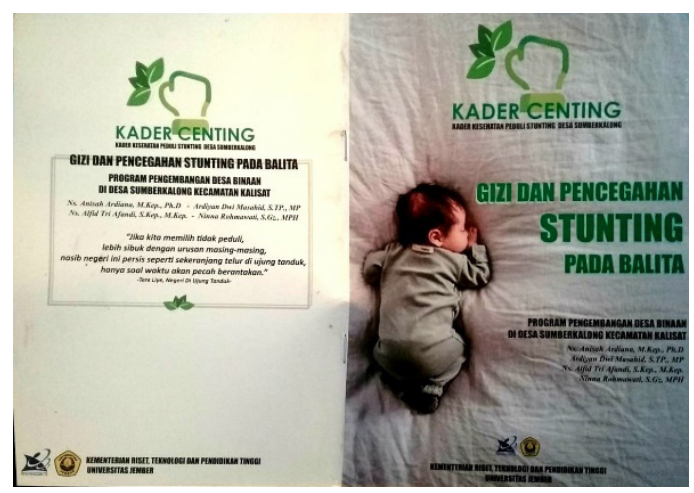

Gambar 6. Buku pegangan Kader

\section{KESIMPULAN}

Berdasarkan hasil kegiatan pengabdian kepada masyarakat ini, maka dapat disimpulkan bahwa dengan pemanfaatan kader kesehatan dalam memaksimalkan pencegahan dan penatalaksanaan balita stunting dapat berjalan dengan baik. Hal ini dapat dibuktikan dengan meningkatnya pengetahuan ibu balita terhadap stunting sehingga ibu balita akan lebih perhatian terhadap status gizi anak balitanya masing-masing. dapat optimal dan maksimal. Dengan adanya penyuluhan dan pendampingan serta monitoring berkala dapat mengoptimalkan kegiatan sehingga akan berdampak pada peningkatan status gizi sehingga mencegah terjadinya stunting.

\section{UCAPAN TERIMA KASIH}

Penulis mengucapkan terima kasih kepada Kemenristek Dikti Republik Indonesia atas bantuan dana Hibah Desa Binaan melalui Universitas Jember pada tahun 2019 dan juga bagi semua pihak yang terlibat dalam kegiatan yang tidak bisa penulis sebutkan satu persatu. 


\section{DAFTAR PUSTAKA}

Afandi, A.T. 2016. Peer Group Support Effectivity Toward The Quality Of Life Among Pulmonary Tuberculosis And Chronic Disease Client : A Literature Review. NurseLine Journal, [S.I.], v. 1, n. 2, p. 219-227, nov. 2016. ISSN 2541-464X. https://jurnal.unej.ac.id/index.php/NLJ/article/ view/4901

Ardiana, A., Purwandari, R. 2011. Pengaruh pemberian tahu-tempe terhadap peningkatan berat badan bayi penderita gizi buruk di Kabupaten Jember. Jurnal Keperawatan Soedirman Vol. 06(2). Pp. 72-80.

Aridiyah, F.O., Rohmawati, N., Ririanty, M. 2014. Faktor-Faktor Yang Mempengaruhi Kejadian Stunting Pada Anak Balita Di Wilayah Pedesaan dan Perkotaan Di Kabupaten Jember. Skripsi. Jember: Universtas Jember.

American Board for Occupational Health Nurse. 2014. The Career Guide to Occupational Health Nursing. Hinsdale: ABOHN.

Badan Pusat Statistik Kabupaten Jember.
2017. Kecamatan Kalisat dalam Angka. Available from: https://jemberkab.bps.go.id/ publication/download.html. Diakses tanggal 04 September 2019 jam 09.00

Kementerian Kesehatan Republik Indonesia. 2018. Cegah Stunting dengan Perbaikan Pola makan, Pola asuh dan Sanitasi (2). Available from: http://www.depkes.go.id/article/ print/18040700002/cegah-stunting-denganperbaikan-pola-makan-pola-asuh-dansanitasi-2-.html. Diakses pada 4 September 2019.

Kementerian Kesehatan RI. 2010. Riset Kesehatan Dasar Badan Penelitian dan Pengembangan Kesehatan Kementerian Kesehatan RI. Jakarta: Kementerian Kesehatan RI.

Yunita, N.W. 2018. Pengertian Stunting dan Solusinya yang Perlu Kamu Tahu. Available from: https://health.detik.com/beritadetikhealth/d-4312866/pengertian-stuntingdan-solusinya-yang-perlu-kamu-tahu. Diakses pada 4 September 2019. 